\title{
101 スタビライザータイプ人工膝関節の動作解析
}

\section{Movement Atralysis of Stabilizer Type Artificial Knee Joint}

\author{
○学 石田 則幸（北見工大院） 正 藤木 裕行（北見工大） \\ 正 小林 道明（北見工大） 正 安田 和則（北大） \\ Noriyuki ISHIDA, Hiroyuki FUJIKI, Michiaki KOBAYASHI \\ Kitami Institute of Technology, Koen-cho 165, Kitami, Hokkaido \\ Kazunori YASUDA, Hokkaido University
}

Key Words : Movement Analysis, Artificial Knee Joint, Stabilizer Type, Posterior Cruciate Ligament

\section{1.緒言}

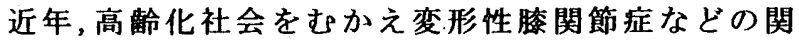
節疾患が増え, 人工膝関節の使用が增加し除痛・支 持・運動の面で多大な恩恵をもたらしている。

本研究では,病態の悪化などに伴い後十字勒帯の切 除を必要とする患者に対して用いられるスタビライ ザータイプ人工膝関節について,静的条件のもとで設 計されているこの人工膝関節が動的条件のもとでは どのような接触状態をしているかを動作测定, 逆動力 学法, 非線形最適化法を用いて動作解析し, その評価 をおこなった。

\section{2.解析方法}

2.1 人工滕䦳解析に用いたスタビライザータ イプ人工膝関節は, 切除された後十字勒帯の機能を補 うために脛骨側コンポーネントのスタビライザーが 大腿骨コンポーネントとかみ合い, 通常のロールバッ クムーブメントを促進するという特徵を持っている. 図 1 に本解析で対象とした人工滕関節（米ストライ カー社製 デルタフィットPPSK）を示す。
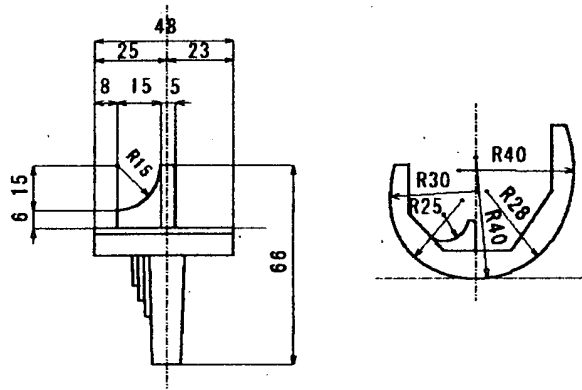

Fig. 1 Stabilizer type artificial knee joint

2.2 動作測定動作测定は, 三次元運動解析装圆 ELITE plus(BTS 社製)を使用し,床反力ならびにその作 用位置の計测には床反力計 Type9286(KISTLER 社製) を使用した。また，測定対象は健常者の步行動作で， 歩調約 $0.8 \mathrm{~Hz}$, 歩楅約 $1.1 \mathrm{~m}$, 歩行速度約 $0.84 \mathrm{~m} / \mathrm{s}$ で あった。

2.3 力学方程式 解析に必要な制約条件として, 各 関節におけるモーメントの釣合いと,滕関節における
力の䑶合い式がある。以下にこれらの式を示す。

く各関節でのモーメントの剑合い式 >

・股関節

$$
-a_{1}\left|F_{1}\right|-a_{2}\left|F_{2}\right|+a_{3}\left|F_{3}\right|+a_{4}\left|F_{4}\right|+M_{h}=0
$$

- 滕関節

$$
\begin{aligned}
& r m_{1} \times F_{1}+r m_{4} \times F_{4}+r m_{5} \times F_{5}+r m_{6} \times F_{6} \\
& +r m_{7} \times F_{7}+\Sigma r l_{j} \times L F_{j}+M_{F P}+M_{k}=0
\end{aligned}
$$

- 足関節

$a_{7} \times F_{7}+a_{8} \times F_{8}-a_{9} \times F_{9}+M_{a}=0$

$M_{h}, M_{k}, M_{a} \quad$ : 各関節モーメント

$\boldsymbol{F}_{\boldsymbol{i}}, \boldsymbol{L} \boldsymbol{F}_{\boldsymbol{j}} \quad$ : 筇力, 勒带力ベクトル

$M_{p} \quad$ ：㯟蓋反力によるモーメント

$a_{i} \quad$ : 筋肉の固定モーメントアーム

$\boldsymbol{r m} \boldsymbol{m}_{i}, \boldsymbol{r} \boldsymbol{l}_{j} \quad$ : 筋, 勒帯の作用点位置ベクトル

<膝関節における力の验合い方程式>

$$
\begin{aligned}
& \Sigma F_{i}+\Sigma L F_{j}+F_{p}+F_{o u t}+C F=0 \\
& \boldsymbol{F}_{\boldsymbol{p}} \quad \text { : 凌蓋反力ベクトル } \\
& \text { Fout : 脸関節力ベクトル } \\
& \boldsymbol{C F} \text { : 関節接触反力ベクトル }
\end{aligned}
$$

2.4 非線形最道化法非線形最適化手法は, その目 的関数として筋疲労をモデル化した筋応力の 3 乗の 総和を用い,これを最小にすることを運動决定基準と した。

2.5 睩関節モデル 数学的解析を可能にするため に次の仮定を置き膝関節をモデル化した。

（1）大腿骨，脛骨は㴊体である.

（2）大腿骨表面は，複数の䯏かな円柘で近似で きる。

（3）脛骨関節面は平面とし前方に $7^{\circ}$ の迎角を持 ว.

（4）大腿骨・脛骨は矢状面内の関節面の 1 点で接 触する。

（5）筇肉・腱等の軟部組織は骨への点付着とし, その力の作用方向は付着点を結ぶ直線方向で ある。

（6）大腿筋，広㬳筋力は，膝蓋腱を介して脛骨に 伝達される。

さらに生体の物性值については文献の值を用い,解 析を行った。

〔No.01-16〕日本機械学会材料力学部門講演会講演論文集〔2001-8.1 3,北見〕 


\section{3.解析結果と㜔繁}

動作测定により得られたデータを用いて，動的条件 でスタビライザータイプ人工膫関節がどのような接 触状態であるかを解析した。なお比韾のために生体膫 関節とスタビライザー部を除去した人工様関節の解 析もおこなった。これらの解析による大跟骨一豚骨接 触状態を図 2,3 に示す.なお,図 3 に示した第二関 節面反力とはスタビライザー部において両コンポー ネントの接触によって生じる接触反力のことである。

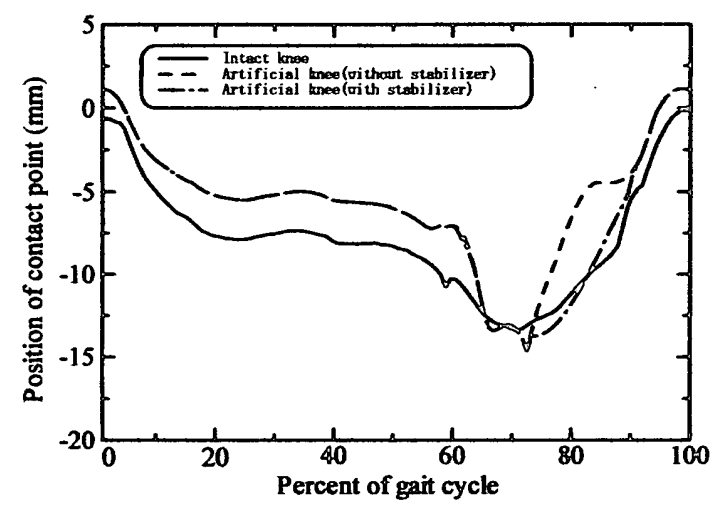

Fig.2 Comparisons of contact point between intact and artificial knee joint during gait

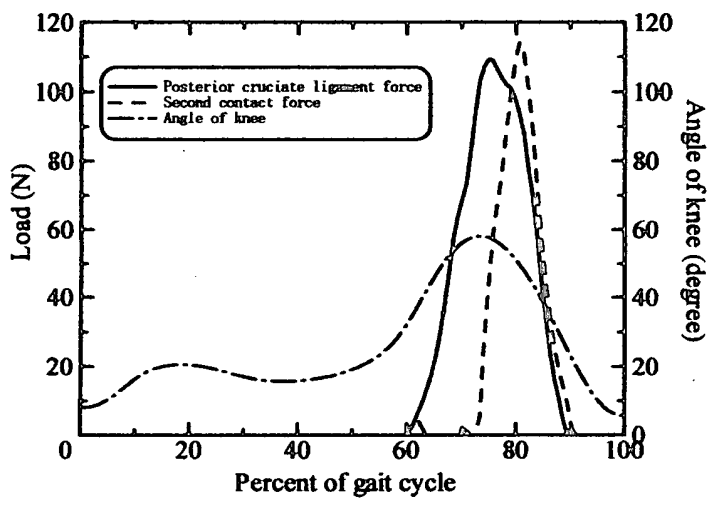

Fig.3 Comparisons of ligament force and second contact force between intact and artificial knee joint during gait

図 2 に示した生体膫関節と人工凌関節の大腿骨一 旺骨接触点位置を比較すると，歩行サイクルの0〜 $60 \%$ 人工腧関節の接触位置が前方に移動している ことが分かる、これは両解析モデルの大腿骨表面形状 の遧いによるものである.さらにスタビライザーのな い人工膝関節では，歩行サイクルの 70〜90\%の遊脚 期において接触位置が大きく前方に移動している、こ れは図 3 に示した後十字朝帯力が発生しないので, ロ 一ルバックムーブメントが促進されていないからで ある。しかし、スタビライザータイプ人工腅関節の場 合，遊脚期において図3に示したスタビライザー部の 接触反力である第二関節面反力の锦きによりロール バックムーブメントが促進され，その動きは生体膘関
節の理想的な接触状態に近づいている.また後十字勒 帯力の最大饂は 109(N)であるのに対して，第二関節 面反力の最大傎も $114(\mathrm{~N})$ と近い值で，スタビライザ 一部が有効に倒いていることが分かる.

図 3 には，膝関節届曲角度もあわせて示したが、こ れと第二関節面反力の関俰よりスタビライザー部が 接触する滕関節角度は屈曲時と伸展時で異なりこれ より動的な解析が必要であることが分かる。

次に生体㬵関節と人工㬵関節の大眼骨一脛骨関節 面反力を図 4 に示す. 歩行サイクルの 0 60\%の立脚 期においてスタビライザータイプ人工滕関節が多少 高い值をとっている.これは生体凌関節に比べ接触点 が最適位置からずれたことで必要以上の筇力が鼣い たことと，接触力の水平成分として摩擦力が発生して いるためである.また遊脚期においてはスタビライザ 一タイプ人工滕関節の関節面反力が生体膝関節と比 べて低い值をとっている.これは遊脚期には䈘力がほ とんど倒かないので,人工膫関節では靭帯の数が少な いぶん関節面反力も低い值をとっているものである.

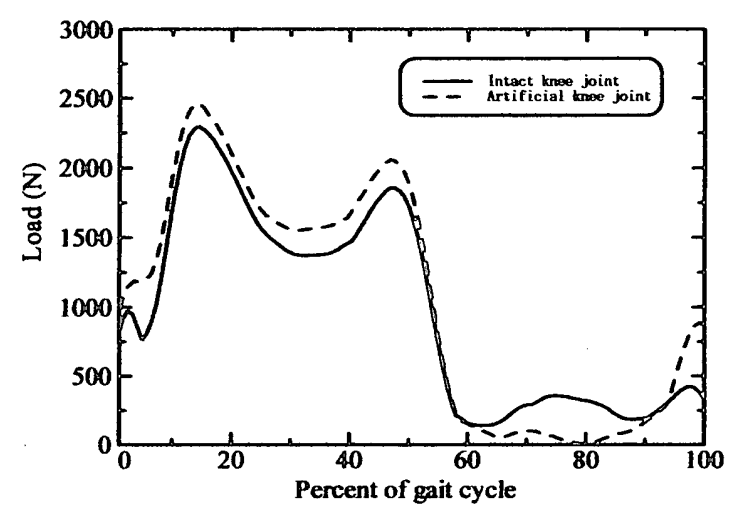

Fig.4 Variation of contact force between intact and artificial knee joint during gait

\section{4. 結言}

生体腺関節とスタビライザータイブ人工膫関節に ついて大腿骨一脛骨接触状態を解新した結果, 以下の ことがわかった。

（1）生体悲関節とスタビライザー部のない人工滕関 節を比較した結果, 後十字鞄带を切除することで 遊脚期のロールバックはあまり促進されず接触 位置は前方に移動する。

（2）スタビライザータイプ人工膝関節の接触状態を 解析した結果,スタビライザー部は歩行動作にお いて切除した後十字靭帯の嘰能を補いロールバ ックムーブメントを促進し,生体膫関節の接触位 置に近づけている。

今後の課題として大腿骨一脛骨関節面反力を用い た人工䐋関節の応力解析をする必要があり,被鈳者つ

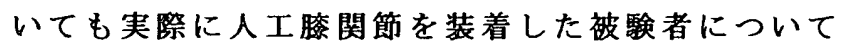
動作測定する必要がある。 